\section{National Competency-Based Standard for School Heads (NCBSSH) status its impact on job satisfaction of school leaders: Base reference for professional enhancement}

\author{
Nazareth, Joselito D. $\bowtie$ \\ Emilio Aguinaldo College, Manila, Philippines (joenaz1969@gmail.com)
}

Received: 7 August $2021 \quad$ Revised: 13 August 2021

Available Online: 16 August $2021 \quad$ DOI: $10.5861 /$ ijrsm.2021.m057

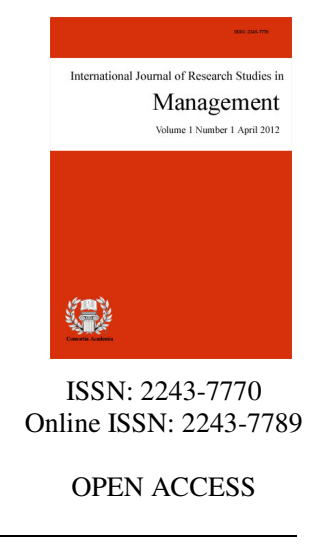

\title{
Abstract
}

This study is conducted to determine the Management Performance of Buenavista District II School Heads under the seven (7) domains of the National Competency Based Standard for School Heads (NCBS-SH). The researcher considered the Descriptive survey as most applicable method in order to evaluate the respondents' strengths and weaknesses in terms of performance and management. Questionnaire as main instrument was then served to target school head respondents in order to gather the data needed. It also revealed in the frequency and distribution of School Head Respondents' Profile the following: age- majority of the respondents belongs to 25-35 years of age, female, whose educational attainment belongs to those with units in Master's Degree, mostly Teachers-In-Charge from elementary level, five and below years of experience as school head and handling six to ten teachers. It further revealed that the school head respondents' management performance was categorized outstanding, particularly on the following domains: Personal and Professional Attributes and Interpersonal Effectiveness, School Management and Operation, Parents Involvement and Community Partnership, creating a Student Centered Learning Climate and School Leadership, respectively. However, the remaining two domains, namely: Instructional Leadership and Human Resource Management and Professional Development fall under very satisfactory, which, therefore recommends the researcher for an enhancement program.

Keywords: school leadership, instructional leadership, professional development, parents' involvement 


\section{National Competency-Based Standard for School Heads (NCBSSH) status its impact on job satisfaction of school leaders: Base reference for professional enhancement}

\section{Introduction}

Effective Management Performance of the school heads of public Elementary and Secondary Schools have contributed largely in the Vision, Mission and Goal of the entire Philippine Education System, by ensuring quality basic education for all (EFA Goal, 2015). This is evident in the current health crisis, every school thru the school head commits to serve in the name of education (RA 9155). While there is great fear due to COVID 19, school leaders were able to craft their respective Learning Continuity Plan (LCP) (dm \#12, s. 2020), as a platform to ensure that learning among all school-aged children are enjoying their right to be educated. Among the Department of Education's parameters to ensure that life-long learning is being catered, and appropriate management strategies are enjoined, the National Competency Based Standard for School Heads (DepEd Order \#32, s. 2010) was served as a tool to monitor the performance of school heads.

The National Competency Based Standard for School Heads (NCBS-SH) is composed of domains and competency strands such as school leadership, instructional leadership, creating a Student Centered Learning Climate, Human Resource Management and Professional Development, Parents Involvement and Community Partnership, School Management and Operation, Personal and Professional Attributes and Interpersonal Effectiveness. All of these domains are supported with competency strands which enumerate how a school head performs in a particular role.

A school head helps the school to attain high level of performance through the utilization of its resources (Lunenburg, 1995). It is expected that school head as leader and manager have the knowledge, skills and ability to promote the success of all students by managing the school organization, operation and resources in a way that promotes a safe, efficient and effective learning environment. According to Kadir (2019), effective management of education depends on the availability and management of resources, accountability and participatory decision-making (good governance) towards the realization of educational goals. Nidadhavolu (2019), also added, the leaders should encourage and motivate their subordinates to perform exceptionally, which will ensure job satisfaction and organizational commitment.

Effective principals are strong educators, anchoring their work on central issues of learning and teaching and continuous school improvement. According to Schmoker (2016), the combination of three concepts constitutes the foundation for positive improvement results: meaningful teamwork; clear, measurable goal; and the regular collection and analysis of performance data. School Heads must lead their school through the goal setting process in which student achievement data is analyzed, improvement areas are identified, and actions for change are initiated. This process involves working collaboratively with staff and school community to identify discrepancies between current and desired outcomes, to set and prioritize goals to help close the gap, to develop improvement and monitoring strategies aimed at accomplishing the goals, and to communicate goals and change efforts to the entire school community. Principals must also ensure that staff development needs are identified in alignment with school improvement priorities and that these needs are addressed with appropriate professional learning opportunities.

To achieve the Education for All objectives by 2015, the Department of Education is pursuing policy reforms under the Basic Education Sector Reform Agenda. Key Reform Thrust 1 of BESRA is School-Based Management. SBM underscores the empowerment of key stakeholders in school communities to enable them to actively participate in the continuous improvement of schools towards the attainment of higher pupil/student learning outcomes. School-based management decentralizes control from the central district office to individual schools as a way to give school constituents-principals, teachers, parents and community members-more control 
over what happens in schools. Often SBM is adopted for the purpose of school improvement. By empowering groups who are closest to the students, school decisions, it is thought, will be better tailored to the particular needs of students, and school performance will improve. (Manual on SBM Practices).

Chan (2014) conducted a study which states that gender of school principals seems to significantly impact their perceptions of their roles and responsibilities. Results of the study indicated that female principals' responses were more agreeable and congruent than those of male principals in all five countries. This is a clear indication that female educators showed more participating interest in school leadership than their male counterpart. Female principals in this study seemed to indicate their willingness and readiness to take a more participatory and collaborative approach in handling daily school business. According to Bertolino, et al (2018), older and younger workers were perceived differently in terms of certain Big Five personality factors and organizational citizenship behavior. These perceived differences generally reflected actual age-related differences on these variables. However, respondents' age moderated many of these effects, such that respondents' perceptions favored their own age group.

In the study conducted by Lee et al. (2015), the award-winning teacher group at the school was able to facilitate the development of professional co-operation and teaching innovation within the school and to transform the school into a learning community. The campus ethics of affiliation, collegiality, and experience-heritage were cultivated at the award-winning elementary school. The school leaders, especially the principal, had a critical impact on the development of the school's teacher culture via their determination and encouragement. Both the school principal and the school's senior teachers played an exemplary and leading role in shaping a high-quality school culture for professional development. As explained by Wallace (2013), effective principals perform five key practices well such as shaping a vision of academic success for all students; Creating a climate hospitable to education; cultivating leadership in others; Improving instruction; Managing people, data and processes to foster school improvement.

Peariso (2011) pointed out that concerning pedagogy, principals held eclectic beliefs, but were united in the beliefs of accountability and the importance of a prescriptive, well designed curriculum. Subjects, gender, ethnicity, and the percentage of instructional leadership delegated were not significantly different in regards to principals' instructional leadership practices or pedagogical beliefs. Significant differences were found among a few specific instructional leadership practices and pedagogical beliefs based on subjects' education level, overall years as a classroom teacher, subject taught as a teacher, overall years as the current principal, and overall years of administrative experience. The findings of the study of Morgan (2015) highlights that the results indicated significant, positive relationships between the independent variable perceived school leadership practices of principals and teachers and the dependent variables perceived classroom management and perceived academic performance. A significant, positive relationship was also found between perceived school leadership practices and perceived school environment.

Stefanski (2016) conducted a study to investigate the role of the family in those partnership models, and discuss implications for productive family-school-community relations. Our analysis of the literature indicates that the role of parents and families differed considerably across the four models. In contrast to the simple family involvement versus family engagement dichotomy found in much of the current literature, we found eight distinct ways in which family roles were envisioned and enacted. According to the study of Đurisic et al. (2017) to comply with the system of integrated support for their students', schools need to build partnership with parents and develop mutual responsibility for children's' success in the educational system. In this way, parental involvement is increased, parents' effort to support schools are encouraged, and they are directly making a positive impact to a successful educational system.

AlShaikhly (2017) revealed that there is an impact of human resource management practices on employees' satisfaction in Jordanian telecommunication companies either collectively or separately. This indicates that human resource management practices play a major role in employees" satisfaction in organization regardless of 
their activities. Abuhanttash (2018) pointed out that Employees' awareness has been extensively considered as an important resource to provide sustainable competitive advantage to organizations. However, in the current awareness economy, one of the challenges faced by AM (Awareness Management) is to manage this resource effectively to build a human capital pool. One of the reasons for this challenge is that awareness in AM is not symmetrically distributed. There is also little empirical research to test HRM and awareness sharing relationships through the lens of employees' perceptions.

People gain awareness through their personal experience and some part of that awareness cannot be expressed or documented easily. Due to competitive pressures, organizations are focusing more on how to manage awareness resources. AM argue that there is a need to develop a mechanism for effective AM in organizations. Needs suitably motivated employees to share their awareness in their organization. HRM can influence employees' motivation and behavior in workplaces to influence their knowledge sharing behavior. By sharing employees' awareness, organizations can improve their knowledge capability and perform better than their competitors. Employees' knowledge gained through experience is often thought to be the property of an individual, but a great deal of knowledge is created and held collectively through awareness sharing between members of an organization. Collaboration and trust, through employees' knowledge sharing behavior, can help to improve organizational capability.

According to Casto (2016), School-community partnering activities promote the education of children, the well-being of families, and the vitality of communities. Partnerships exist to create afterschool and summer activities for children as well as to promote literacy and ease the transition to middle school. The primary obstacle is organization, including the time and resources to create and maintain partnerships. Geographic isolation affects volunteer activity in the school. Community connections are considered as horizontal (local) and vertical (school district) ties for the school. Place-based education is described as a form of partnering that could enhance the educational experience of students while simultaneously creating horizontal ties for the school and its community. As explained by Kladifko (2013) in her study, School leaders must have knowledge and understanding of the various external and internal entities in their school community. Partnerships, with a focus on communication and interaction with diverse community leaders and professionals, are essential for school success. It is a given that a principal must develop a collaborative partnership with his/her parents and staff, but your external school environment encompasses a much larger scope of diverse community entities. The study of Gross (2015) claimed that School-community partnerships play an essential role in successful schools, often providing supports and resources to meet staff, family, and student needs that go beyond what is typically available through school. Reciprocally, community partners benefit from their relationships with schools, including learning about schools' inclusive culture. To better understand strong community partnerships and what fosters their development, we conducted focus groups with community partners of five schools.

In the study conducted by Ndyali (2013), attempted to analyses the roles of the head of schools in the achievement of academic performance in community secondary schools in Mbeya Urban. The CSEE results show that performance has been deteriorating each year. Despite the vast research studies done by various scholars, little is known about the roles of the school heads in relation to the students' academic performance. Cruz et al. (2016) pointed out that school heads exhibited very satisfactory level in performing their managerial functions in all management areas identified. It also revealed that there were significant differences in the managerial performance of school heads in the areas of vision, mission-goals, financial and budgeting, physical plant and facilities, community relations and management of school improvement plan. The data on the weaknesses of school heads in performing managerial functions in identified areas of school management provided the basis in proposing an enhancement plan that may be used in improving their functions and in providing a key to more development programs for school heads in the division.

According to Pepito (2019), School performance is based on the six dimensions of school-based management which are school leadership, internal stakeholders' participation, external stakeholders' participation, school-based resources and school performance accountability. The school heads as school leaders 
had to exert more efforts on the stakeholders' participation, school improvement process, and school performance accountability. They have to increase their occupational and professional competencies. In the study conducted by Kadtong (2016), the schools are SBM-PASBE accredited with level 1 of practice. In general, SBM is implemented according to the guidelines set by DepEd. As to the SBM implementation in its five dimensions, data shows that the five dimensions of SBM were observed and practiced often by the schools under this study.

Zhang (2018) pointed out that in this digital information age, more and more people are over-dependent on electronic communication, such as e-mail, voice mail audio-conferencing and video-conferencing. The significance of how people interact with one another at work has now widely been recognized, more especially in face-to-face interaction compared to the world of virtual communication. Effective interpersonal skills have become a vital part of professional contexts. According to Cisler (2017), Collaboration between school counselors and principals is increasingly important in this accountability era. School counselors and principals could benefit from learning more about the others' respective roles to enhance their working partnership towards increasing academic achievement.

Habegger (2018) pointed out that The principals focused on creating a positive school culture by engaging in activities (e.g., making a point to visit each teacher before class started, greeting students as they entered the building, and providing common planning time for teachers) that developed both the students' and adults' capacity for learning and success. I also found two significant types of activities on which the principals concentrated and in which they engaged to help create positive culture: creating a sense of belonging and providing a clear direction for all involved-students, teachers, parents, and community. According to Cisler (2017), team leader as the most important role, while supervisor was rated as the least important. A principal should work cooperatively with staff to ensure more effective use of their skills. While, the task of a principal in making decisions on staff development programs was not necessarily expected by the practicing teachers. All respondents considered organization! coordination as the most important area within which a principal should provide more leadership, while curriculum or instructional improvement and innovation were regarded as the least important.

The framework of this study is anchored on Management Theories such as Scientific Management Theory, Systems Management Theory, Contingency Management Theory, Authoritarian and Participative Theories.

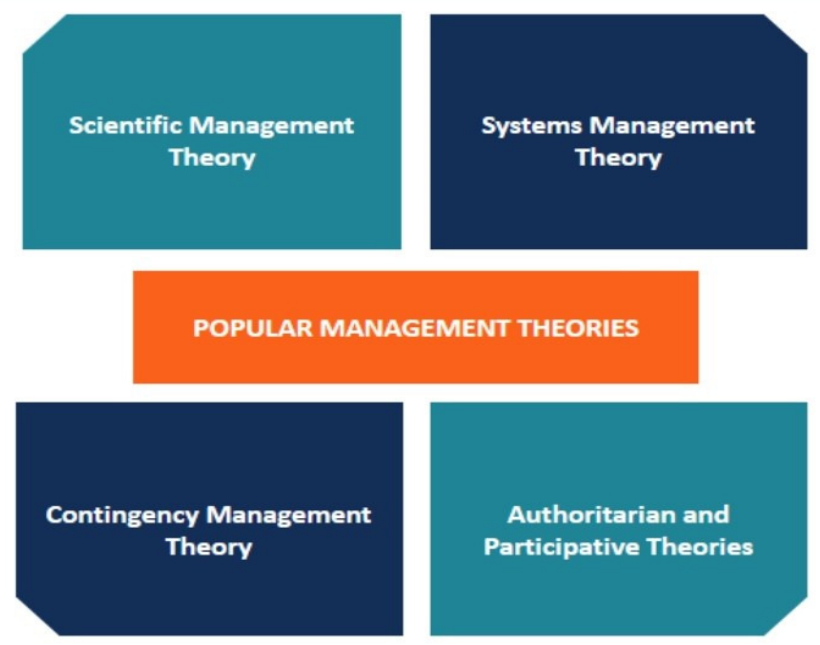

Figure 1. Management Theory

The framework of this study is anchored on Management Theories such as Scientific Management Theory, Systems Management Theory, Contingency Management Theory, Authoritarian and Participative Theories.

Scientific Management Theory: American mechanical engineer Frederick Taylor, who was one of the earliest management theorists, pioneered the scientific management theory. He and his associates were among 
the first individuals to study work performance scientifically. Taylor's philosophy emphasized the fact that forcing people to work hard wasn't the best way to optimize results. Instead, Taylor recommended simplifying tasks so as to increase productivity.

The strategy was a bit different from how businesses were conducted beforehand. Initially, a factory executive enjoyed minimal, if any, contact with his employees. There was absolutely no way of standardizing workplace rules and the only motivation of the employees was job security. According to Taylor, money was the key incentive for working, which is why he developed the "fair day's wages for a fair day's work" concept. Since then, the scientific management theory has been practiced worldwide. The resulting collaboration between employees and employers evolved into the teamwork that people now enjoy.

Systems Management Theory: System Management offers an alternative approach to the planning and management of organizations. The systems management theory proposes that businesses, like the human body, consists of multiple components that work harmoniously so that the larger system can function optimally. According to the theory, the success of an organization depends on several key elements: synergy, interdependence, and interrelations between various subsystems. Employees are one of the most important components of a company. In practice, managers are required to evaluate patterns and events in their companies so as to determine the best management approach. This way, they are able to collaborate on different programs that they can work as a collective whose rather than as isolated units.

Contingency Management Theory: The main concept behind the contingency management theory is that no one management approach suits every organization. There are several external and internal factors that will ultimately affect the chosen management approach. The contingency theory identifies their variables that are likely to influence an organization's structure: the size of an organization, technology being employed, and style of leadership. Fred Fiedler is the theorist behind the contingency management theory. Fiedler proposed that the traits of a leader were directly related to how effectively he led. According to Fiedler's theory, there's a set of leadership traits handy for every kind of situation. It means that a leader must be flexible enough to adapt to the changing environment. The contingency management theory can be summed up as follows:

Theory $\mathbf{X}$ and Theory Y: do you believe that every individual gets maximum satisfaction from the work they do? Or are you of the opinion that some view work as a burden and only do it for the money? Such assumptions influence how an organization is run. The assumptions also form the basis of Theory $\mathrm{X}$ and Theory Y. Douglas McGregor is the theorist credited with developing these two contrasting concepts. More specifically, these theories refer to two management styles: the authoritarian (Theory X) and participative (Theory Y).

In an organization where team members show little passion for their work, leaders are likely to employ the authoritarian style of management. But if employees demonstrate a willingness to learn and are enthusiastic about what they do, their leader is likely to use participative management. The management style that a manager adapts will influence just how well he can keep his team members motivated. Theory $\mathrm{X}$ holds a pessimistic view of employees in the sense that they cannot work in the absence of incentives. Theory Y, on the other hand, holds an optimistic opinion of employees. The latter theory proposes that employees and managers can achieve a collaborative and trust-based relationship. Still, there are a couple of instances where theory X can be applied. For instance, large corporations that hire thousands of employees for routine work may find adapting this form of management ideal.

As shown in Figure 2, the researcher in the first box will determine the profile of the school heads respondents in terms of age, gender, educational attainment, School Level, position/rank, number of years as school head, and number of teachers handled. The second box will determine the assessment of the school heads' respondents as regards management on School Leadership, Instructional Leadership, creating a Student Centered Learning Climate, Human Resource Management and Professional Development, Parents Involvement and Community Partnership, School Management and Operation, Personal and Professional Attributes and Interpersonal Effectiveness. 


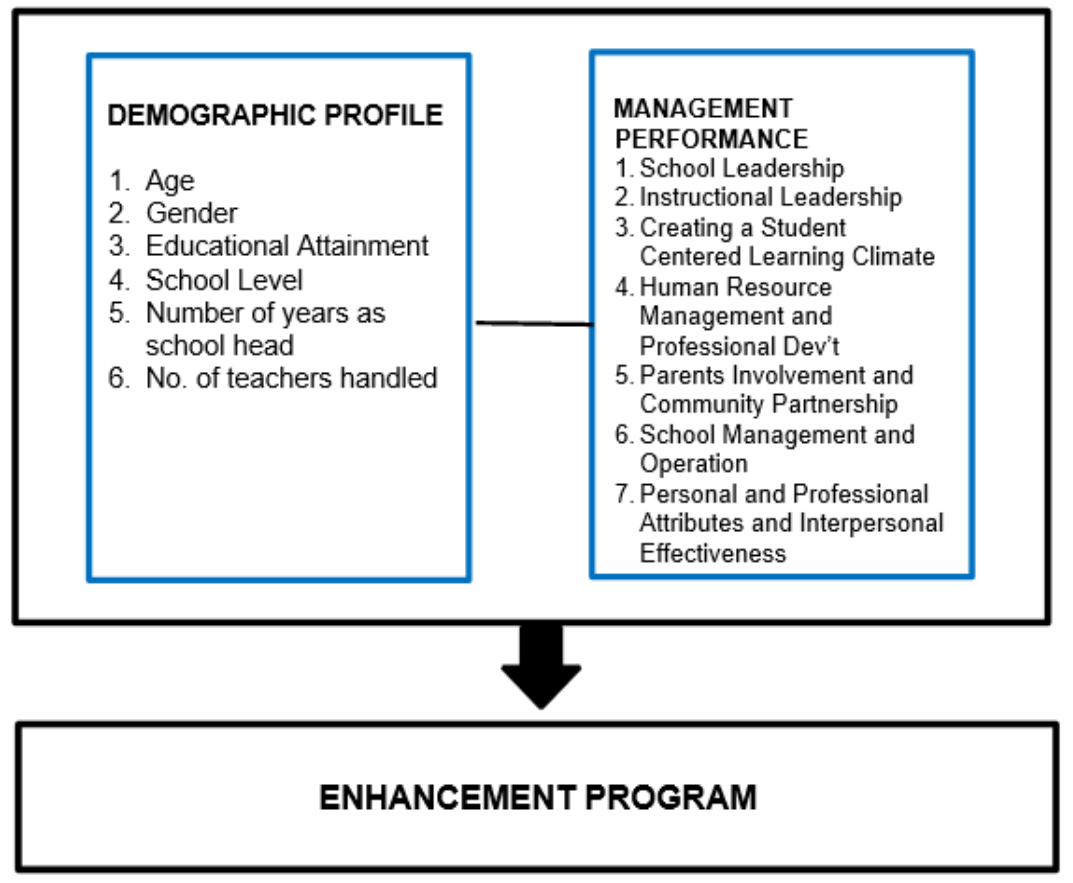

Figure 2. Research Paradigm

This study will determine the following: 1 . What is the demographic profile of the respondents' in terms of: age, gender, educational attainment, School Level, position/rank, number of years as school head, and number of teachers handled?; What is the management performance of the respondents in terms of: School Leadership, Instructional Leadership, Creating a Student Centered Learning Climate, Human Resource Management and Professional Development, Parents Involvement and Community Partnership, School Management and Operation, Personal and Professional Attributes and Interpersonal Effectiveness?

This study will test the hypothesis that there is no significant difference between demographic profile and Management Performance of the respondents. This study is designed to benefit the following: Parents will know that their involvement in school is for the sake of the learners. Students will enjoy their right to learn safely and effectively. Teachers will be benefited in terms of fully understanding their school head's roles in managing the school in all aspects pertaining to effective delivery of learning. This scope of this study is limited only to the 14 School Heads' of Buenavista District II of Quezon.

In order for the intended readers to fully understand the paper, the researcher has given both the conceptual and operational definition of the terms used in this paper.1) School Leadership as used in this study, it refers to the process of enlisting and guiding the talents and energies of school heads, teachers, students and parents toward achieving common educational aims. 2) Instructional Leadership. As used in this study, it is generally defined as the management of the curriculum and instruction by a school principal. 3) Creating a Student Centred Learning Climate. As used in this study, it refers to the focus of instruction shifted from the teacher to the student with the end goal of developing students who are autonomous and independent, by placing the responsibility of learning in the hands of the students. 4) Human Resource Management and Professional Development. As used in this study, it refers to the design of formal systems to ensure the effective and efficient use of human talent to accomplish the goals of the organization. 5) Parents Involvement and Community Partnership. As used in this study, it refers to a shared responsibility and reciprocal process whereby schools and other community agencies and organizations engage families in meaningful and culturally appropriate ways, and families take initiative to actively supporting their children's development and learning. 6) School Management and Operation. As used in this study, it refers to effective planning, organizing and managing the human, 
physical and financial resources of the school, as well as identifying the areas of needs. 7) Personal and Professional Attributes and Interpersonal Effectiveness. As used in this study, it refers to the qualities of a school head which exemplifies in the business environment such as professionalism which includes standards for behaviour and the ability to do what their employer expects of them. For Interpersonal Effectiveness, as used in this study, refers to the ability to interact with others in the most acceptable manner.

\section{Methodology}

This research used the descriptive research method in order to achieve the purpose which is to determine the management performance of the School Heads of Buenavista District II. This study focused on Buenavista District II School Heads of schools such as Maligaya NHS, Hagonghong Integrated High School, San Pedro NHS, Hagonghong ES, Bucal ES, Siain ES, San Pedro ES, San Diego ES, San Isidro Ilaya ES, Esperanza ES, Villa ES, Villa Veronica ES, Villa Veronica ES and Esperanza ES. The participants of the study were Fourteen (14) Elementary and Secondary School Heads coming from Buenavista District II. They were selected Simple purposive technique for it is limited only for the School Heads only of the said district.

This study utilized the following instruments including Survey Questionnaire. Tables and figures were used to provide clearer understanding of the data presented as answers to the problem of the study. The researcher prepared a questionnaire based on The National Competency Based Standard for School Heads (NCBS-SH) that is composed of domains and competency strands such as school leadership, instructional leadership, creating a Student Centered Learning Climate, Human Resource Management and Professional Development, Parents Involvement and Community Partnership, School Management and Operation, Personal and Professional Attributes and Interpersonal Effectiveness. The respondents were asked to choose their preferred response by checking the number option based on their profile, background, and perception along the given area.

\section{Table 1}

Rating scale criteria for sub problem 2

\begin{tabular}{ccc}
\hline Scale & Numerical Rating & Equivalent \\
\hline 4 & $3.51-4.00$ & Outstanding \\
3 & $2.51-3.50$ & Very Satisfactory \\
2 & $1.51-2.50$ & Satisfactory \\
1 & $1.00-1.50$ & Fairly Satisfactory \\
\hline
\end{tabular}

The Data collected in this study underwent a process of data analysis. A letter addressed to the Public Schools District Supervisor and the School Head-respondent were given by the researcher tha served as permission to conduct and participate to the study. The following statistical tools were used in this study. The researcher used the Percentage frequency distribution and weighted mean was used to determine the demographic profile of the respondents and the management performance of the School Heads. The researcher was strictly observing the following ethical considerations including objectivity and integrity, respect of the research subjects' right to privacy and dignity and protection of subjects from personal harm, presentation of research findings, and misuse of research role.

\section{Results and analysis}

The gathered data are presented here together with the analysis and interpretation based on the stated objectives of the study. These include the profile of the School Head respondents in terms of age, gender, educational attainment, rank/position, school level, Number of years as school head and number of teachers handled. It also included here the management performance of Buenavista District II respondents as follows: School Leadership, Instructional Leadership, creating a Student Centered Learning Climate, Human Resource Management and Professional Development, Parents Involvement and Community Partnership, School Management and Operation, and Personal and Professional Attributes and Interpersonal Effectiveness. 


\subsection{Profile of the School Head Respondents}

Tables 1 presents the frequency distribution of the respondents' profile in terms of their age, gender, educational attainment, rank/position, School Level, Number of years as school head and number of teachers handled.

Table 2

Frequency distribution of school heads respondents' profile

\begin{tabular}{|c|c|c|}
\hline Age & Frequency & Percentage \\
\hline $25-35$ & 5 & $38.46 \%$ \\
\hline $36-45$ & 2 & $15.38 \%$ \\
\hline $46-55$ & 3 & $23.08 \%$ \\
\hline 56 and above & 3 & $23.08 \%$ \\
\hline Total & 13 & $100 \%$ \\
\hline \multicolumn{3}{|l|}{ Gender } \\
\hline Male & 6 & $46.15 \%$ \\
\hline Female & 7 & $53.85 \%$ \\
\hline Total & 13 & $100 \%$ \\
\hline \multicolumn{3}{|l|}{ Educational Attainment } \\
\hline Bachelor's degree & 3 & $23.08 \%$ \\
\hline w/ Master's units & 6 & $46.15 \%$ \\
\hline Master's degree & 3 & $23.08 \%$ \\
\hline w/ Doctoral units & 1 & $7.69 \%$ \\
\hline Doctoral degree & 0 & 0 \\
\hline Total & 13 & $100 \%$ \\
\hline \multicolumn{3}{|l|}{ Rank/Position } \\
\hline Teacher-In-Charge & 6 & $46.15 \%$ \\
\hline Head Teacher & 3 & $23.08 \%$ \\
\hline Principal & 4 & $30.77 \%$ \\
\hline Total & 13 & $100 \%$ \\
\hline \multicolumn{3}{|l|}{ School Level } \\
\hline Elementary & 10 & $76.92 \%$ \\
\hline Secondary & 3 & $23.08 \%$ \\
\hline Total & 13 & $100 \%$ \\
\hline \multicolumn{3}{|l|}{ Number of Years as School Head } \\
\hline $0-5$ Years & 6 & $46.15 \%$ \\
\hline $6-10$ years & 2 & $15.38 \%$ \\
\hline $11-15$ years & 4 & $30.77 \%$ \\
\hline 16 and above & 1 & $7.69 \%$ \\
\hline Total & 13 & $100 \%$ \\
\hline \multicolumn{3}{|l|}{ Number of Teachers Handled } \\
\hline 5 and Below & 4 & $30.79 \%$ \\
\hline $6-10$ & 5 & $38.46 \%$ \\
\hline $11-15$ & 2 & $15.38 \%$ \\
\hline 16 and above & 2 & $15.38 \%$ \\
\hline Total & 13 & $100 \%$ \\
\hline
\end{tabular}

Table 2 shows the frequency and distribution of 13 School Heads Respondents' Profile in terms of the following: age- majority of the respondents belongs to 25-35 years of age with $38.46 \%$. Gender reveals that female had the highest number of respondents with $53.85 \%$. When it comes to Educational attainment, there were 6 respondents or $46.15 \%$ with units in master's degree. While in terms of rank or position, Teachers-In-Charge got the highest percentage with $46.15 \%$. As to school level or assignment of school heads, majority of which comes from elementary level with 10 respondents or $76.92 \%$. Their number of years as school head represents $0-5$ years with 6 or $46.15 \%$ respondents comprises the highest percentage. Lastly, the table shows that in terms of number of teachers handled, there were 5 respondents or $38.46 \%$ which got the highest frequency. 
Nazareth, J. D.

\subsection{Perception of teacher respondents as regards students' relaxation}

Table 2 presents the Management Performance of School Head -respondents regarding School Leadership, Instructional Leadership, creating a Student Centered Learning Climate, Human Resource Management and Professional Development, Parents Involvement and Community Partnership, School Management and Operation, and Personal and Professional Attributes and Interpersonal Effectiveness.

Table 3

Management performance of Buenavista District II school heads

\begin{tabular}{|c|c|c|c|}
\hline Domains & Mean & Interpretation & Rank \\
\hline A. School Leadership & 3.52 & Outstanding & 5 \\
\hline B. Instructional Leadership & 3.35 & Very Satisfactory & 7 \\
\hline C. Creating a Student Centered Learning Climate & 3.58 & Outstanding & 3.5 \\
\hline D. Human Resource Management and Professional Development & 3.44 & Very Satisfactory & 6 \\
\hline E. Parents Involvement and Community Partnership & 3.58 & Outstanding & 3.5 \\
\hline F. School management and Operation & 3.59 & Outstanding & 2 \\
\hline G. Personal and Professional Attributes and Interpersonal Effectiveness & 3.69 & Outstanding & 1 \\
\hline General Weighted Mean & 3.53 & Outstanding & \\
\hline
\end{tabular}

Legend: 3.51-4.00 Outstanding; 2.51-3.50 Very Satisfactory; 1.51-2.50 Satisfactory; 1.00-1.50 Fairly Satisfactory

Table 2 reveals the Mean Percentage, interpretation and rank obtained by school head respondents in different domains of the National Competency Based Standard for School Heads with a General Weighted Mean of 3.53. It also shows in the table that Personal and Professional Attributes and interpersonal Effectiveness placed rank 1 with an overall MPS 3.69. This was followed by the School Management and Operation with a total 3.59 MPS. However, Parents Involvement and Community Partnership and Creating a Student Centered Learning Climate got the same MPS of 3.58. The fifth rank was the School Leadership domain with an MPS of 3.52, while Human Resource Management and Professional Development got 3.44 MPS, and Instructional Leadership domain got the lowest MPS of 3.35.

\section{Discussion}

Following are the summary of findings obtained through the conduct of this study including the conclusions and recommendations formulated by the researcher.

\subsection{Summary of findings}

Profile of the school head respondents

$>$ Age-Majority of the School Head Respondents belong to 25-35 years of age or 38.46\%

$>$ Gender-There were more female respondents than male with the total of 7 or $53.85 \%$

$>\quad$ Educational Attainment-Six out of 13 school head respondents or 46.15\% had units in master's degree.

$>$ Rank/Position-6 out of 13 school head respondents or $46.15 \%$ are Teacher-In-Charge.

$>$ School Level-10 out of 13 school head respondents or $76.92 \%$ came from elementary level.

$>\quad$ Numbers of years as school Head - There were 6 out of 13 respondents or $46.15 \%$ belongs to those with the shortest experience as school head.

$>\quad$ Number of Teachers Handled-5 out of 13 school head respondents or $38.46 \%$ belongs to small schools.

\subsection{Management performance of Buenavista District II school heads}

90 Consortia Academia Publishing (A Partner of Tourism Educators and Movers of the Philippines) 
NCBSSH status its impact on job satisfaction of school leaders: Base reference for professional enhancement

Based from the result of the study, school head respondents as to management and performance reveals that Personal and Professional attributes got the highest rank among all seven domains. This was followed by School Management and Operation, as second. The third highest in rank was Parents Involvement and Community Partnership and Creating a Student Centered Learning Climate. While School Leadership got rank five, Human Resource Management and Professional Development got rank six. It means that Instructional Leadership being the lowest among all domains require an enhancement program.

\section{Conclusions}

Based from the findings of the study, the following conclusions are made:

$>\quad$ Age, Gender, Educational Attainment, Rank/Position, School Level, and Number of years as School Head and Number of Teachers Handled revealed significant factors in determining management performance of school head respondents. As shown in table 2, majority of the respondents belonged to the youngest age bracket and female, with master's units, belonged to teacher in-charge, elementary school heads, with shortest years of experience to handle a school and those school heads from a small school, with small number of teachers.

$>\quad$ It indicated in the result of the survey that the overall rating of school head respondents fall under a general weighted mean of outstanding, particularly on domains aside from instructional leadership and Human Resource Management and Professional Development. Hence, the researcher, after careful analysis, made a conclusion that the possibility to still improve the respondents' performance on the identified domains is high.

\subsection{Recommendations}

Based from the conclusions of this study, the following recommendations are forwarded:

$>\quad$ The demographic profile of the school head respondents, after being tabulated and examined also revealed that there is a need to include in the proposed program for enhancement purposes.

$>\quad$ Every learning institution's goal is to produce high performing school leaders, who in turn will produce well-rounded individuals. However, such goal can be attained effectively through an enhancement program. A program that will capacitate and enhance effective target performance, particularly in instructional leadership and Human Resource Management and Professional Development. The first giving focus on assessment for learning, developing programs and/or adopting existing programs on school-wide curriculum, implementing programs for curriculum innovation and enrichment, and instructional supervision. The latter domain with lesser output productivity such as on creating a professional learning community, recruitment and hiring and managing performance of teachers and staff.

\subsection{Proposed professional enhancement program for Buenavista District II school heads}

Rationale - The program deals with the improvement of the management performance of the School Heads in Buenavista District II. Specifically, these concern on the school leadership, instructional leadership, creating students centered learning climate, human resource management and professional development, parents involvement and community partnership, school management and operation, personal and professional attributes and interpersonal effectiveness. Therefore, the program will assess and monitor the enhancements of management performance of the school heads.

Objectives - The main objective of this enhancement program is to enhance the management performance of the school heads in Buenavista District II. Specifically, it aims the following: 
$>\quad$ To support the necessary resources needed for the identified insufficiencies in the management performance.

$>\quad$ To enhance the management performance by the school heads in maximizing his full potentials based on the finding in the study that is least evident and performed by following the suggested strategies and activities in the program.

$>$ To monitor himself in performing his duties as school head as compliance in the management performance requirements using the National Competency Based Standard for School Heads (NCBS-SH).

$>\quad$ To manage the school effectively through applying the knowledge gained from this enhancement program.

\begin{tabular}{|c|c|c|c|c|c|}
\hline \multicolumn{6}{|c|}{ ENHANCEMENT PROGRAM FOR SCHOOL HEADS OF BUENAVISTA DISTRICT II } \\
\hline Target & Activity/ies & $\begin{array}{l}\text { Persons } \\
\text { Involved }\end{array}$ & Time Frame & Budget & $\begin{array}{l}\text { Performance } \\
\text { Indicators }\end{array}$ \\
\hline $\begin{array}{l}\text { instructional } \\
\text { leadership }\end{array}$ & $\begin{array}{l}\text { Regular attendance } \\
\text { to Staff Conference } \\
\text { every first Monday } \\
\text { of the Month }\end{array}$ & $\begin{array}{c}\text { PSDS, School } \\
\text { Principal, Head } \\
\text { Teachers, } \\
\text { Teachers } \\
\text { In-Charge } \\
\end{array}$ & $\begin{array}{c}\text { August } \\
\text { 2021-March } \\
2022\end{array}$ & $\begin{array}{l}\text { Buenavista } \\
\text { District II } \\
\text { Revolving } \\
\text { Fund }\end{array}$ & $\begin{array}{l}\text { Competent School } \\
\text { Heads; updated } \\
\text { school leaders with } \\
\text { Curriculum } \\
\text { Innovation }\end{array}$ \\
\hline & $\begin{array}{c}\text { Participation to } \\
\text { Virtual Huntahan sa } \\
\text { Quezon - School } \\
\text { Heads' Edition, } \\
\text { headed by the } \\
\text { Schools Division } \\
\text { Superintendent }\end{array}$ & $\begin{array}{c}\text { SDS, Asst. } \\
\text { SDS, Public } \\
\text { Schools } \\
\text { District } \\
\text { Supervisors and } \\
\text { School Heads }\end{array}$ & $\begin{array}{c}\text { Aug.-Nov } \\
2021 . \\
\text { 2021/Nov. -F } \\
\text { ebruary } \\
\text { 2022/Feb. } 22 \\
\text { to May } \\
\text { 2022/May -A } \\
\text { ug. 2022 } \\
\end{array}$ & $\begin{array}{l}\text { N/A (Personal } \\
\text { Budget) }\end{array}$ & $\begin{array}{l}\text { Updated School } \\
\text { Heads with } \\
\text { Instructional } \\
\text { Supervision and } \\
\text { relevant leadership } \\
\text { practices }\end{array}$ \\
\hline & $\begin{array}{c}\text { Hosting Cluster } \\
\text { Learning Action Cell } \\
\text { (CLAC) }\end{array}$ & $\begin{array}{c}\text { Public Schools } \\
\text { District } \\
\text { Supervisor, } \\
\text { School } \\
\text { Principals, Head } \\
\text { Teachers, } \\
\text { Master } \\
\text { Teachers, } \\
\text { Teachers } \\
\text { In-Charge } \\
\end{array}$ & Quarterly & $\begin{array}{c}\text { N/A } \\
\text { (Stakeholders } \\
\text { donation) }\end{array}$ & $\begin{array}{c}\text { Leadership and } \\
\text { Curriculum updates }\end{array}$ \\
\hline $\begin{array}{c}\text { Human } \\
\text { Resource } \\
\text { Management } \\
\text { and } \\
\text { Professional } \\
\text { Development }\end{array}$ & $\begin{array}{l}\text { Regular attendance } \\
\text { to Staff Conference } \\
\text { every first Monday } \\
\text { of the Month }\end{array}$ & $\begin{array}{c}\text { PSDS, School } \\
\text { Principal, Head } \\
\text { Teachers, } \\
\text { Teachers } \\
\text { In-Charge }\end{array}$ & $\begin{array}{c}\text { August } \\
\text { 2021-March } \\
2022\end{array}$ & $\begin{array}{c}\text { Buenavista } \\
\text { District II } \\
\text { Revolving } \\
\text { Fund }\end{array}$ & $\begin{array}{c}\text { School Plan for } \\
\text { Professional } \\
\text { Development } \\
\text { (SPPD) and } \\
\text { Individual Plan for } \\
\text { Professional } \\
\text { Development } \\
\text { (IPPD), as well as } \\
\text { recruitment and } \\
\text { hiring }\end{array}$ \\
\hline
\end{tabular}

\section{References}

Abuhanttash, A. (2018). The impact of human resource management on awareness employee and organization capability. University of North Texas.

AlShaikhly, N. (2017). The impact of human resource management practices on employees' satisfaction: A field study in the Jordanian telecommunication companies. Middle East University. Amman Jordan.

Casto, H. (2016). Just one more thing I have to do: School-community partnerships. School Community Journal, 26(1). http://www.schoolcommunitynetwork.org/SCJ.aspx

Chan, T., et al. (2014). Roles and responsibilities of school principals: A five country comparison. The SRCEA 
NCBSSH status its impact on job satisfaction of school leaders: Base reference for professional enhancement

Yearbook. Mississippi State University Press.

Cisler, A., et al. (2018). Principals: What are their roles and responsibilities? University of Wyoming.

Cruz, C., et al. (2016). Towards enhancing the managerial performance of school heads. International Review of Management and Business Research, 5(2).

Đurišić, M. (2017). Parental involvement as an important factor for successful education. CEPS Journal, 7(3).

Gross, J. (2018). Strong school-community partnerships in inclusive schools are "part of the fabric of the school. We count on them". School Community Journal, 25(2).

http://www.schoolcommunitynetwork.org/SCJ.aspx

Habegger, S. (2018). The principal's role in successful schools: Creating a positive school culture.

Kadir, A. (2019). Good governance issues in education system and management.

Kadtong, M (2018). School-based management in the operations and performance of public elementary schools. Proceedings Journal of Education, Psychology and Social Science Research.

Kladifko, R. (2018). Practical school community partnerships leading to successful educational leaders. California State University Northridge.

Lee, H., et al. (2015). Principal leadership and its link to the development of a school's teacher culture and teaching effectiveness: A case study of an award-winning teaching team at an elementary school. International Journal of Education Policy \& Leadership, 10(4). https://doi.org/10.22230/ijepl.2015v10n4a555

Morgan, L. (2016). The influence of school leadership practices on classroom management, school environment, and academic underperformance. Walden University Scholar Work. https://scholarworks.waldenu.edu/dissertations

Ndyali, H. (2013). The role of school head in enhancing students' academic performance in community secondary schools in Mbeya Urban. Open University of Tanzania.

Nidadhavolu, A. (2018). Impact of leadership styles on employee job satisfaction and organizational commitment - A study in the construction sector in India Akhila Nidadhavolu. Western Kentucky University.

Peariso, J. (2016). A study of principals' instructional leadership behaviors and beliefs of good pedagogical practice among effective California high schools serving socioeconomically disadvantaged and English learners. Liberty University.

Pepito, G., et al. (2019). School-based management and performance of public elementary school heads: Basis for technical assistance plan. International Journal of Innovation and Research in Educational Sciences, $6(1)$.

Rayens, W., et al. (2018). Creating a student-centered learning environment online. Journal of Statistics Education, 26(2), 92-102. https://doi.org/10.1080/10691898.2018.1475205

Stefanski, A. (2016). Beyond involvement and engagement: The role of the family in school-community partnerships. School Community Journal, 26(2). http://www.schoolcommunitynetwork.org/SCJ.aspx

Walters, G. (2016). The effectiveness of a human resources function within a public utility. University of South Africa.

Zhang, L. (2018). Importance of interpersonal skills at work towards managing people in an educational context. Advances in Economics, Business and Management Research, 54. https://doi.org/10.2991/msmi-18.2018.6 
Nazareth, J. D.

94 Consortia Academia Publishing (A Partner of Tourism Educators and Movers of the Philippines) 